\title{
A glimpse into the secular change of mantle-derived magmatism at the transition between Neoarchean and Paleoproterozoic
}

\author{
MARCO FIORENTINI ${ }^{1}$, STEFANO CARUSO ${ }^{2}$ AND \\ ANDREA GIULIANI ${ }^{3}$ \\ ${ }^{1}$ University of Western Australia \\ ${ }^{2}$ CET-University of Western Australia \\ ${ }^{3}$ ETH Zurich \\ Presenting Author: marco.fiorentini@uwa.edu.au
}

The secular change in the geochemical and isotopic composition of mantle magmatism informs on the key changes that our planet has endured during its complex and long-lived geodynamic evolution. We provide here a glimpse into the temporal window comprised between $\sim 3.0-2.0 \mathrm{Ga}$, when it is thought that the bulk of the Earth's continental crust as well as a large proportion of its metallogenic endowment were formed. We focus on the Yilgarn Craton of Western Australia as a natural laboratory and showcase how the indelible signal of anomalous multiple sulfur isotopes $\left(\Delta^{33} \mathrm{~S} \neq 0\right)$ can be used to track the evolving nature of mantle domains that were tapped through time. Throughout the Mesoarchean, Al-depleted komatiite magmas and associated nickel-sulfide deposits dominantly display $\Delta^{33} \mathrm{~S}<0$. This signature reflects the interaction between mantle magmatism and mafic-dominated crustal environments, and persists into the granitoids in the oldest lithospheric blocks of the craton. In the Neoarchean, Al-undepleted komatiites become dominant, with associated nickel-sulfide deposits displaying consistently positive $\Delta^{33} \mathrm{~S}$ signatures that, overall, indicate the interaction with more mature crustal environments. In a temporal window comprised between 20-50 million years after komatiite magmatism, volatile-rich calc-alkaline lamprophyres were emplaced. Coevally, the largest gold mineralising event that Earth ever witnessed took place, soon followed by widespread generation of granitoid magmas throughout the craton. The Neoarchean multiple sulfur isotope signature of mantle-derived magmas and associated mineralisation in the Yilgarn Craton is consistently positive. In the Paleoproterozoic, ultramafic lamprophyres are emplaced in the most juvenile parts of the craton, potentially reflecting the thermal influence of large igneous provinces located several thousand kilometres away. At its margins, significant reworking of Archean material occurs for several hundred million years, controlling the sulfur budget of localised Proterozoic domains, the episodic emplacement of clusters of alkaline magmatism outboard of the craton, as well as the size and nature of precious and base metal deposits. The geochemical and isotopic composition of mantle-derived magmas preserved in the Yilgarn Craton provides insights into the dynamic interaction between evolving mantle magmatism and changing crustal environments, allowing to decipher planetary magmatic cycles and predict the localisation of large mineral provinces. 